\author{
학교 텃밭의 지속적인 운영방안에 관한 연구 ${ }^{\dagger}$ \\ - 서울특별시 초등학교의 학교 텃밭 실태조사를 바탕으로 -

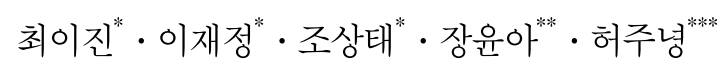 \\ "서울특별시농업기술센터 · "국립원예특작과학원 · "*한국농촌경제연구원

\section{A Sustainable Operation Plan for School Gardens - Based on a Survey of Elementary School Gardens in Seoul} \\ Choi, I-Jin ${ }^{*} \cdot$ Lee, Jae Jung ${ }^{*} \cdot$ Cho, Sang Tae ${ }^{*} \cdot$ Jang, Yoon $\mathrm{Ah}^{* *} \cdot \mathrm{Heo}$, Joo Nyung ${ }^{* * *}$ \\ *Seoul Metropolitan Agricultural Technology Center \\ ${ }^{* *}$ National Institute of Horticultural and Herbal Science, RDA \\ ${ }^{* * *}$ Korea Rural Economic Institute
}

\begin{abstract}
This study surveyed 599 elementary schools in Seoul to provide measures for the quantitative expansion and sustainable operation of environmentally-friendly school garden. Of all schools, 161 schools had formed and were operating school gardens. The total area of school gardens was $166,901 \mathrm{~m}^{2}$ and the mean area was $131.2 \mathrm{~m}^{2}$ in elementary, junior high and high schools in Seoul. Meanwhile, the total area of school gardens was $65,493 \mathrm{~m}^{2}$ and the mean area was $363 \mathrm{~m}^{2}$ in 161 schools that participated in the survey, indicating $1.15 \mathrm{~m}^{2}$ per student. Of these schools, $11.8 \%$ were operating gardens themselves, while $50.3 \%$ were operating gardens that had been newly renovated or environmentally improved by institutional support projects after initially managing gardens themselves. According to the locations of school gardens, mixed-type gardening (a combination of school gardening and container vegetable gardening) accounted for 34.8\%, followed by school gardening at $32.9 \%$, container vegetable gardening at $29.2 \%$, and suburb community gardening at $3.1 \%$. Those in charge of garden operations were teachers at $51.6 \%$, comprising the largest percentage. Facilities built when forming the garden included storage facilities for small-scale greenhouses and farming equipment at $26.1 \%$, accounting for the largest percentage. No additional facilities constructed accounted for $21.7 \%$. The greatest difficulty in operating gardens was garden management at 34.2\%. The most needed elements for the sustainable operation of gardens were improvement in physical environment and the need for hiring a paid garden, each accounting for 32\%. The most important purpose for school gardening was creating educational environments $(81.6 \%)$. The major source for gaining information on garden management was consultation from acquaintances (67.8\%). Schools that utilize plant waste from gardens as natural fertilizers accounted for $45.8 \%$ of all schools. Responses to the impact of operating school gardens for educational purpose were positive in all schools as'very effective'in $63.2 \%$ and 'effective'in $36.8 \%$. This study was meaningful in that it intended to identify the current status of the operation of school gardens in elementary schools in Seoul, support the formation of school gardens appropriate
\end{abstract}

\footnotetext{
${ }^{\dagger}$ : 본 연구는 농촌진흥청 공동연구사업(과제번호: PJ01185902) 지원에 의해 이루어진 것임.

Corresponding author: I-Jin Choi, Seoul Metropolitan Agricultural Technology Center, Seoul 06795, Korea, Tel.: 82+2-6959-9343

E-mail: ijin2080@seoul.go.kr
} 
for each school with sustainable operation measures, implement a high-quality education program, develop teaching materials, expand job training opportunities for teachers in charge, devise measures to support specialized instructors, and propose the need for a garden management organization.

\section{Key Words: School Farm, Garden Management, Gardening, Operating Gardens}

\section{국문초록}

본 연구는 학교 텃밭의 양적인 확대뿐만 아니라, 지속적인 운영 방안을 제시하는 것을 목적으로 한다. 서울시내 599 개 초등학교를 대상으로 설문조사를 실시한 결과, 설문조사에 응답한 161 개 학교 모두가 학교 텃밭을 조성 - 운영하고 있었다. 서울시 초·중·고 포함 학교 텃밭 면적은 $166,901 \mathrm{~m}^{2}$, 평균 $131.2 \mathrm{~m}^{2}$ 이고, 설문조사에 응답한 161 개교의 학교 텃밭 면적은 $65,493 \mathrm{~m}^{2}$, 평균 $363 \mathrm{~m}^{2}$, 학생 1 인당 $1.15 \mathrm{~m}^{2}$ 로 조사되었다. 학교 자체적으로 조성 · 운영하는 경우는 $11.8 \%$, 학교 자체적으로 조성하여 운영하다가 기관 지원 사업을 통해 재조성 혹은 환경개선을 하여 운영하는 경우가 $50.3 \%$ 로 조사되었다. 학교 텃밭은 조성위치에 따라 혼합형(교내 텃밭과 상자텃밭 조합)이 $34.8 \%$ 로 많았고, 교내 텃밭형이 $32.9 \%$, 상자 텃밭형이 $29.2 \%$, 교외 근린텃밭을 활용하는 교외 텃밭형 학교도 $3.1 \%$ 였다. 텃밭 운영 담당자는 담당교사가 $51.6 \%$ 로 가장 높았으며, 텃밭 조성 시에 함께 조성된 시설물은 소형 온실 - 농기구 보관함이 $26.1 \%$ 로 가장 많았으나, 별도의 기반시 설이 함께 조성되지 않은 경우도 $21.7 \%$ 였다. 텃밭 운영에 있어서 어려운 점은 텃밭 관리가 $34.2 \%$ 로 가장 높았고, 텃밭의 지속적 운영을 위해 가장 필요한 요소로 물리적 환경 개선과 유급관리인 고용이 필요하다는 의견이 각 $32 \%$ 로 높게 조사되었다. 학교 텃밭 조성목적은 교육환경 조성 $(81.6 \%)$ 이 가장 높았으며, 텃밭관리에 필요한 정보는 주로 주변 자문 (67.8\%)을 통해서 얻고 있었다. 텃밭에서 발생하는 식물쓰레기를 친환경적으로 퇴비화하는 학교는 $45.8 \%$ 였다. 학교 텃밭 의 교육적 활용이 학생들에게 미치는 영향에 대해서는 매우 효과적이라는 응답이 $63.2 \%$, 효과적이라는 응답이 $36.8 \%$ 로 조사대상 학교 전체가 긍정적인 응답을 하였다. 본 연구는 서울지역 초등학교를 대상으로 텃밭 운영 실태를 파악하고, 지속적인 운영방안으로 학교 실정에 맞는 텃밭조성 지원, 양질의 교육프로그램적용 및 교구개발, 담당교사 직무연수 확대, 전문 강사 지원방법 모색, 텃밭관리조직 운영의 필요성을 제안하는데 의의가 있다고 생각된다.

주제어: 학교 농장, 텃밭조성, 텃밭운영, 텃밭관리

\section{I. 서론}

학교 텃밭은 학교 교정을 활용하여 학생들이 직접 운영하는 체험공간으로 교과과정과 연계한 체험학습, 학교급식과 연계 한 친환경 채소재배 등으로 농업과 생태의 중요성을 체험으로 익히고, 나아가 미래농업에 대한 잠재력을 배우는 학습공간으 로 활용될 수 있다. 학교 텃밭은 도시 녹지 공간을 확보하는 역 할을 하며, 또한 학교 텃밭에서 이루어지는 활동은 학생들에 게 자연의 쾌적함을 제공하고, 정서를 풍부하게 해 전인적 성 장과 삶의 질 항상을 도울 수 있는데, 이러한 점에서 학교 텃밭 의 필요성이 증대하고 있다. 서울시는 2012년부터 학교 텃밭 조 성사업을 꾸준히 시행하고 있으며, 학교 텃밭이 운영되고 있는 학교는 2013년에는 469개였으며, 2016년은 1,272개로 58.3\% 가 학교 텃밭을 운영하고 있다(SMG, 2017). 또한 서울시교육 청에서는 초등학생을 중심으로 텃밭, 화분, 화단, 학교 숲을 활 용할 수 있는 사업을 추진하고 있다. 서울시뿐만 아니라, 경기
도 등 각 지자체에서도 학교농장 조성사업을 시행하여 학교 텃 밭의 양적인 확대가 이루어졌다. 농림축산식품부와 농촌진흥청 은 도시농업공간의 확보를 위해 도시농장, 농업공원, 학교 텃 밭, 마을텃밭, 자투리텃밭, 옥상텃밭 등의 조성을 2013년부터 2017년까지 수행하였으며, 제2차 도시농업육성 계획을 발표하 고 지속적으로 진행할 것이다(MAFRA. 2017, 2018).

도시농업의 확산과 중요성이 부각됨에 따라 학교 텃밭의 양 적인 확대뿐만 아니라, 교사와 학생, 학부모 요구도를 파악하여 문제점을 개선하여 내실 있게 운영할 수 있는 방안을 통해 학 교 텃밭의 지속적 운영을 위한 방법을 제시할 필요성이 있다. 조성 초기 활발히 운영되었더라도 학교장이나 담당교사 교체 이후 소극적으로 변하거나 학교 텃밭 운영에 관한 경험과 지식 이 없어 혼란을 겪는 경우가 발생하고 있다. 학교 텃밭에 관한 연구는 텃밭 가꾸기 교육프로그램 개발과 학생들을 대상으로 한 교육효과를 구명하는 연구가 다양한 분야에서 많이 보고되 고 있는데, 운영 주체 대상 실태 관련 조사 및 운영방안을 제시 
한 연구는 미비하다. 따라서 본 연구에서는 서울지역 초등학교 599 개교 중 237개의 초등학교를 대상으로 텃밭 조성 - 운영 관리 및 교육적 활용현황을 파악하고, 이를 통해 학교 텃밭의 지속적인 운영 방안을 제시하고자 한다.

\section{II. 이론적 배경}

\section{1. 학교 텃밭}

학교 텃밭은 아직 명확한 사전적 정의가 없고 학교마다 스 쿨팜, 스쿨가든, 팜스쿨, 학교농장, 학교 정원, 배움 텃밭, 교육 농장, 학교학습원, 생태텃밭 등으로 불리고 있다. Jang and $\mathrm{Oh}$ (2012)는 학교 텃밭을 '학교 또는 학교 인근에 상자나 노지 를 활용한 텃밭을 만들어 학생들이 작물을 가꾸고 수확하는 과 정을 통해 먹을거리와 자연 순환에 대한 이해를 높이고 신체, 정신 건강과 함께 생명과 자연에 대한 감수성을 되살려나갈 수 있도록 교육프로그램을 도입한 공간'이라고 정의하고 있다. 도시농업의 육성 및 지원에 관한 법률에서는 '학생들의 학습 과 체험을 목적으로 학교의 토지나 건축물 등을 활용한 농업 이라고 정의하고, 도시농업의 유형 중 '학교 교육형 도시농업' 으로 분류하고 있다. 또한 도시농업이란 "도시 지역에 있는 노 지, 건축물 또는 다양한 생활공간을 활용하여 농작물을 경작하 고 재배하는 행위'를 말하며, 도시농업인은 '환경 친화적인 농 법을 사용하여 안전한 농산물을 생산하도록 힘써야 하고, 도시 농업에 이용되는 농자재 등을 안전하게 관리 또는 처리함으로 써 생활환경이 오염되지 않도록 힘써야 한다고 규정하고 있다. 종합해 보면 학교 텃밭은 학생들이 놀고, 일하고, 배우고, 생각 하는 곳으로 학교의 다양한 공간을 활용하여 농작물을 재배하 는 장소이며, 작물재배는 환경 친화적인 농법을 사용하고, 학생 들의 학습과 체험을 목적으로 운영관리가 되어야 한다.

\section{2. 학교 텃밭 조성 및 운영관리}

우리나라의 학교 텃밭은 농림수산식품부의 도·농 교류 5 개 년 계획의 일환으로 초등학생들의 농업·농촌에 대한 이해를 높이고, 건전한 농산물 소비자로 육성하기 위한 2010년 팜스쿨 시범사업으로 조성되었다. 농촌진흥청은 도시농업시범사업을 통해 조성하였고, 경기도와 경기농림진흥재단)은 2009년부터 3 년간 학교농장 조성사업을 시행하였다. 서울시는 2012년부터 꾸준히 학교 텃밭 조성사업을 시행하여 177 개교를 조성하였고, 학교 텃밭을 이용한 농작물 가꾸기, 텃밭동아리 운영, 텃밭 생 산 농산물을 이용한 식생활 체험, 어머니 텃밭 도우미 운영, 수 경재배 텃밭 전시를 해 다양한 텃밭 체험활동을 통한 바른 식 생활 습관과 바른 인성 함양, 지역사회 및 유관기관과 함께 하 는 식생활교육 $\mathrm{CRM}$ 구안, 지역의 소외된 계층에게 김장배추
제공하기 등으로 공동체를 활성화시키고 있다(SMG, 2017).

일본의 경우, 식(食)교육 중요성을 강조하며, 2005년에 식 육기본법이 시행되었고, 사이타마 현에서는 초·중등학교 학 교농장 조성사업을 지원하고 있다. 2009년부터 초·중학교를 대상으로 아이들이 식물의 파종에서 수확까지 체험할 수 있는 '학교농장' 설치를 지원하고, 기업참여를 촉진하는 사업을 진행 하여 학교단위로 농원을 설치하고, 심신 발육단계에 있는 아 동과 학생이 농업체험활동을 통해 생명과 자연, 환경과 식품 등에 관해 이해를 심화함과 동시에 정서와 살아가는 힘을 몸 에 익히는 것을 목표로 운영하고 있달.

미국의 경우에도 '학교 정원 가꾸기'가 꾸준히 진행되어 캘 리포니아 주에는 $57 \%$ 의 학교에 교육용 정원이 조성되었고 (Moon et al., 2012), 뉴욕 주에는 200여 개 이상의 학교에 스쿨 팜이 조성되었다. 유아 비만을 줄이고 미국의 모든 젊은 사람 들이 평생 동안 살 수 있고, 건강한 서식지를 만들 수 있도록 목표를 설정하여 운영하는 Alliance for a Healthier Generation 도 있다.

학교 텃밭 유형은 공간과 목적에 따라 노지형, 습지형, 자투 리형, 인공지반형, 화분형, 화단형으로 분류하였고(Jang et al., 2011), $\operatorname{Kim}(2014 \mathrm{~b})$ 은 초등학교 텃밭운영 실태 분석 및 활성화 방안 연구에서 학교 텃밭 종류를 크게 노지 텃밭, 상자텃밭, 옥 상텃밭으로 구분하였다. 노지 텃밭은 학교 울타리 내의 땅에 조성된 텃밭으로 독립된 공간에 텃밭만을 위해 조성한 것으로 농촌에서 흔히 볼 수 있는 텃밭을 의미하며, 가장 고전적인 형 태이다. 화단 텃밭은 학교에만 있는 독특한 형태로, 학교 화단 일부에 꽃이나 나무대신 텃밭식물을 심고 관리하는 형태이다. 상자 텃밭은 옥상을 제외한 학교 내 공간에 상자나 화분 등을 이용하여 조성된 것으로 노지 텃밭이나 화단 텃밭을 조성하기 어려운 환경의 학교에서 상자나 화분에 양질의 흙과 퇴비를 섞고, 그 곳에 모종이나 씨앗을 심어 채소를 심는 텃밭이다. 옥 상텃밭은 조성 공간이 학교 옥상인 텃밭으로 상자텃밭의 한 형태이다. 농촌진흥청에서는 초등학교 어린이를 위한 교육용 옥상정원 모델을 개발하였는데 녹지부족으로 정원활동을 할 수 없는 도심 초등학교 어린이들을 위하여 학교옥상에 설치할 수 있는 관리혼합형 정원으로 체험과 생태학습이 가능하도록 정원과 텃밭이 혼합된 형태로 구성하였으며, 전국의 도시 초 등학교에 설치하여 학생 및 교사가 교육활동에 활용하도록 하였다.

각 학교의 공간 특성에 따라 학교 텃밭은 자체적으로 또는 기관 등에서 조성하는 것이 있으며, 학교 자체적으로 조성하여 운영하다가 기관 지원 사업을 통해 재조성 혹은 환경개선을 하는 경우도 많다. 학교 텃밭 관리는 담당교사, 행정직원, 교 장 - 교감, 전담 관리자가 책임자가 되어 운영되고 있다. 도시농 업 업무를 담당하고 있는 공무원을 대상으로 한 설문조사를 실 시하여 정부의 제도-기술적 맞춤형 지원방법, 담당교사 및 지 
역사회 도시농업 전문인력 양성 등에 관해 제안이 보고된 바 있다(Park and Ahn, 2013). 학교 텃밭 실태분석은 주로 농촌 지역보다는 도시지역을 중심으로 이루어지고 있는데, 서울시 노원구 · 송파구 초등학교 텃밭 이용 현황조사(Yu et al., 2012), 도시농업 관련 실태조사, 학교 텃밭 운영 현황조사가 보고되었 으며, 학생들을 대상으로 교육장소로서의 텃밭 실태를 파악하 고, 이를 이용한 교과와 연계된 교육프로그램 개발을 통해 활 성화방안을 제시하고 있다(SMG, 2017). 학교 텃밭 관련 서울 강남교육지원청과 북부교육지원청에 대한 조사결과, 학교 텃 밭 형태는 노지 텃밭의 비율이 가장 높았고, 텃밭활동 시간은 교과 수업시간이며, 재배 작물은 교과 과정과 연계하여 선택하 여 운영하였다. 텃밭 관리 담당교사 대부분이 관련 교육 연수 나 교육의 경험이 없어 연수가 필요하다고 하였다. 학교에서는 환경교육과 창의인성 교육을 위해 텃밭이 필요하고, 도움이 된 다고 하였으며, 텃밭활동의 어려움으로 활동시간 부족과 공간 이 부족하다고 하였다. 교사는 $65 \sim 130 \mathrm{~m}^{2}$ 미만 규모의 노지 텃밭을 희망하는 학급에 배정하여 관리하는 것을 선호하였다 (Kim, 2014b).

\section{3. 학교 텃밭의 교육적 활용}

학교 텃밭을 활용한 교육은 교사와 학생이 텃밭에서 식물을 재배하는 과정과 재배한 식물을 활용하는 모든 체험활동을 말 한다. 우리나라의 교양농업교육에 해당되는 학교 텃밭 활용 수 업은 초등학교에서는 실과 교과를 통해 시행되고 있다. 2009년 개정 실과 교육과정에서 농업 영역의 교육 내용은 '생활 속의 동 - 식물'과 '생활 속의 동 - 식물 이용'의 2개 단원으로 편성 되어 있어 교과 연계 수업도 활발히 운영되고 있다. 학교 텃밭 교육은 정규 교과 과정 수업뿐만 아니라, 방과 후 수업, 동아 리 활동 시간에 이루어지고 있다. 창의적 체험활동 시간에는 융 합교육의 일환으로도 활용되는 학교가 많아지는 실정이다. 학 교 텃밭 체험 활동과 초등 교양농업교육은 초등학생에게 일 에 대한 긍정적 태도 변화뿐만 아니라, 농업에 대한 인식을 증진시키고, 환경 태도와 자아 존중감, 감성지능과 성취동기 등 에 긍정적인 영향을 주고, 정원기반교육은 학문적 기술, 개인 적 발달, 사회적 발달, 도덕 발달, 직업적 혹은 생존 기술, 삶의 기술들을 포함하는 기초 교육의 모든 측면들에 기여한다고 보 고되고 있다(Arden and Pringle, 2010; Jung and Bang, 2008; Kwack et al., 2007; Kim, 2009; Lee and Kim, 2014; Oh and Choi, 2006; Son et al., 2015). 어린이 농업생태교육을 위한 찾 아가는 학교농장은 친환경농산물 학교급식사업을 지원하기 위 해 경기도(남양주시, 성남시 소재) 지역 5 개 초등학교를 중심 으로 추진하여 도시농업에 대한 바른 이해와 농촌자원의 가치 를 새롭게 인식하는 계기를 마련하였다.

일본 사이타마현에서는 어린이들에게 체험활동의 기회를 제
공하여 학습의욕 고취, 바람직한 근로관, 취업관 육성, 타인을 생각하는 마음 등 풍부한 인간성 육성을 도모하기 위해 '사이 타마 어린이 70 만 명 체험활동'을 추진하였고, 각 초등학교에 서는 교류체험, 직장체험, 근로생산체험 등 단계별 다양한 체험 활동을 진행하며, 학생들의 올바른 인간상 확립과 자율적인 학습능력 및 사고능력, 창의력 향상, 적성 계발 등을 위하여 각 학교에서 학교 텃밭 교육도 '총합학습' 일환으로 운영하고 있다 ${ }^{3)}$. 미국의 경우, NGA(National Gardening Association)는 1972년부터 36년간 인간, 식물, 환경에 대한 연구를 해오고 있 으며, 식물을 기반으로 하는 교육으로서 학교 정원 운영 방법 에 대한 직무교육을 하고 있는 협회가 있다. 캘리포니아 주의 학교 텃밭 프로그램은 과학, 수학, 국어, 환경, 영양, 건강 등의 과목을 종합적으로 배울 수 있도록 교사, 농업전문가, 영양사 들이 모여 텃밭 농업 교육 프로그램을 만들어 운영하고 있는데, 샌프란시스코 내 115 개 학교에 텃밭이 있고, 주 전체에 1,000 여 곳 이상으로 확대되고 있다. Life Lab Science Program은 1978 년에 캘리포니아 샌터크루즈에 있는 Green Acres 초등학교 학 생들과 선생님들에 의해 시작된 작은 가든으로부터 시작되었 고, 과학, 영양소, 사회, 수학, 예술, 글쓰기 등과 같은 풍부한 내용을 탐험할 수 있게 하여 아이들이 기본적인 학업 내용과 더불어 책임감 있는 시민이 될 수 있도록 교육프로그램을 운영 하고 있다.

식물을 가꾸는 활동에서 교육적 효과는 신체적, 정신적으로 건강한 삶을 살 수 있는 원동력을 만들어주는데, 학교 텃밭과 같은 식물환경이 양호한 학생들은 그렇지 못한 학교에서 생활 하는 학생들에 비하여 우울증 수준이 낮고, 자아존중감, 정서적 안정감, 대인관계, 인지능력, 인성발달과 안정에 유의미한 영향 을 줄 수 있다(Kim, 2009; Hong and Kim, 2017). 학교 텃밭 교육은 인지능력, 사회적, 정서적, 신체적, 환경적으로 효과가 있는데, 텃밭 활동을 통해 새로운 지식과 식물재배 기술을 배 우고 활용함으로써 창의성을 기를 수 있으며, 모둠별로 활동할 경우, 의사소통능력과 사회성이 발달하여 친구관계 개선에 도 움이 된다(Lee et al., 2017). 도시텃밭과 텃밭교육의 중요성 에 대한 연구(Kim, 2014a)에서 학교 텃밭 교육의 효과를 흙의 소중함과 계절의 변화를 느끼며, 감각이 살아나고, 과학적 인식 과 인과관계를 길러준다고 하였다. 또한 땀의 의미와 수확의 기쁨을 알게 되고, 자연계의 순환과 생명에 대한 원리를 알게 된다고 하였다.

학교 텃밭 교육에 활용할 수 있는 교육프로그램은 다양하게 개발되어 있어 학교 특성에 맞게 적용되고 있는데, 농촌진흥청 에서는 유아 · 초등학생을 대상으로 과학, 수학, 국어 교육과정 과 연계하여 지도할 수 있는 원예통합프로그램 매뉴얼인 '텃밭 에 다 있네'를 개발하였으며, 현장 요구사항을 반영하여 농업 및 자연에 대한 효과적 체험학습을 위한 초등학교 내 스쿨팜 조성 모델 및 교구개발을 하였다(Jung et al., 2013). 서울시에 
서도 교과융합교육에 활용할 수 있는 아두이노를 활용한 원예 체험프로그램 스마트텃밭 매뉴얼과 $3 \mathrm{D}$ 프린터를 활용한 우 리가 그린 텃밭매뉴얼 ${ }^{4}$ 을 발간하여 학교 텃밭 교육에 활용하 며, 창의성 증가, 교우관계 개선 효과를 보고하였다(Lee et al., 2017a, Lee et al., 2018).

\section{III. 연구방법}

본 연구는 서울지역 초등학교 599개교 초등학교를 대상으로 텃밭 조성 및 운영현황을 파악하기 위하여 2회에 걸쳐 설문조 사를 수행하였다. 1차 설문조사는 2016년 3월 서울지역 내 599 개 초등학교를 대상으로 협조 공문을 발송하여 실시되었으며, 기존 학교농장 지원사업 참여 학교 포함, 161 개교의 응답을 분 석하였고, 2차 설문조사는 2016년 8월 서울특별시농업기술센 터 ‘학교 텃밭 교사 직무연수’에 참가한 초등학교 교사와 2016 년 학교농장 지원사업 참여 학교를 포함한 서울지역 76개 초 등학교 교사를 대상으로 이루어졌다. 설문조사 구성은 Table 1 과 같다.

1 차 설문조사는 학교 텃밭 조성 현황과 개략적인 운영과 교 육현황을 조사하였으며, 2차 조사는 1차 설문조사 문항을 포함 하여 운영과 관리, 교육적 활용 부분을 보다 세부적으로 조사 하였다. 학교 텃밭 유형을 교내 노지형, 교외 노지형, 옥상 노지
형, 옥상 상자형, 노지 상자형 5 가지 유형으로 구분하였고, 일 반사항(주소지, 학급 및 학생규모 등), 텃밭 조성(조성목적, 부 지 확보, 식물 선정, 만족도 등), 운영 및 관리(관리노력, 관리 정보의 획득, 연수교육 수요, 텃밭 관리상 어려운 점 등), 활용 현황(텃밭 교육의 수업연계 여부, 연계 수업 과목, 참여 대상 및 횟수, 수업 효과 등) 등을 포함한 내용을 조사하였다. 조사 내용은 빈도분석으로 응답수와 백분율을 통한 순위를 제시하 였다. 학교 텃밭 조성 현황은 응답수가 많았던 1차 조사 결과 를 분석하였으며, 운영 관리 및 교육현황은 세부적인 내용이 포함된 2차 조사 결과를 분석하였다. 1차 응답수 161 개교와 2 차 응답수 76 개교를 기준으로 자료를 정리하였으며, 문항에 따라 중복응답이 가능한 경우 실제 응답수에 따랐다.

\section{IV. 결과 및 고찰}

\section{1. 학교 텃밭 현황}

서울의 도시텃밭 면적은 2011년 29ha에서 2016년 143ha로 약 5 배 증가하였는데, 그 중 주말 농장면적이 $52.7 \%$ 로 가장 높고, 학교 텃밭 면적은 $11.4 \%$ 이다. 서울특별시 학교 개수는 유치원, 초등학교, 중학교, 고등학교를 포함해 총 2,182개교 (KEDI, 2016)이고, 학교 텃밭이 운영되고 있는 학교는 2013년

Table 1. Composition of the questions in this survey

\begin{tabular}{|c|c|c|}
\hline Classification & The first survey & The second survey (added questions) \\
\hline General information & $\begin{array}{l}\text { School name } \\
\text { Number of classes and students } \\
\text { Location of school }\end{array}$ & $\begin{array}{l}\text { Type of school } \\
\text { Number of employees }\end{array}$ \\
\hline Construction & $\begin{array}{l}\text { Year of construction } \\
\text { Type of school garden } \\
\text { Area of school garden } \\
\text { Subject of setting up } \\
\text { Facility in school garden }\end{array}$ & $\begin{array}{l}\text { Purpose for setting up school garden } \\
\text { Securement of space for school garden } \\
\text { Satisfaction about school garden }\end{array}$ \\
\hline Operational management & $\begin{array}{l}\text { Subject of running } \\
\text { Annual school garden budget } \\
\text { Difficulty in running school garden }\end{array}$ & $\begin{array}{l}\text { Selection plants for school garden } \\
\text { Way to dispose of farm produce sewage } \\
\text { Acquisition method of information about gardening } \\
\text { Training contents necessary for managing gardens } \\
\text { Lack of managing school garden } \\
\text { Plan for grant use } \\
\text { The most necessary for managing school garden }\end{array}$ \\
\hline Facility supporting & $\begin{array}{l}\text { Available of material supporting } \\
\text { Status of material supporting } \\
\text { Satisfaction of material preparation method }\end{array}$ & \\
\hline Education & $\begin{array}{l}\text { Presence of education program } \\
\text { Grades involved in the activity } \\
\text { Instructor of gardening classes }\end{array}$ & $\begin{array}{l}\text { Classes or time when the school garden is used } \\
\text { Academic subject in which the school garden is used } \\
\text { Current and desired gardening class interval } \\
\text { How to prepare materials for gardening classes } \\
\text { Satisfaction of school garden on students } \\
\text { Difficulty in continuing gardening classes }\end{array}$ \\
\hline Number of the questions & 19 & 49 \\
\hline
\end{tabular}


에는 469개였으며, 2016년은 1,272개로 58.3\%가 학교 텃밭을 운영하고 있다(SMG, 2017). 2012년 “도시농업 육성 및 지원에 관한 법률'의 시행 및 지자체의 조례 제정과 활성화 시책에 따라 특 - 광역시를 중심으로 하여 학교 텃밭의 조성 및 운영이 급격히 증가한 것으로 판단되어진다(AUAC, 2015; MAFRA, 2013).

설문조사지를 발송한 599개 초등학교 중 설문조사에 응답 한 161개 학교를 대상으로 분석하였다. 2012년 이후 서울시 지 원으로 학교 텃밭을 조성한 학교는 연평균 35개교로 2014년 까지는 초등학교를 중심으로 학교 텃밭이 조성되었으나, 초등 학교 텃밭이 정착하면서 중·고등학교로 텃밭 조성이 확대되 는 추세이다(Figure 1 참조). 서울특별시 초·중·고 포함 학 교 텃밭 면적은 $166,901 \mathrm{~m}^{2}$, 평균 $131.2 \mathrm{~m}^{2}(\mathrm{SMG}, 2017)$ 이고, 1 차 설문조사에 응답한 161 개교의 학교 텃밭 면적은 $65,493 \mathrm{~m}^{2}$, 평균 $363 \mathrm{~m}^{2}$, 학생 1 인당 $1.15 \mathrm{~m}^{2}$ 로 나타났다(Table 2 참조). 설 문조사 분석을 위해 학교 텃밭 조성주체, 유형, 구비 시설, 운 영주체, 운영비용, 참여대상을 빈도와 백분율로 나타내었는데, 학교 텃밭은 학교 자체적으로 조성·운영하는 경우는 $11.8 \%$, 학교 자체적으로 조성하여 운영하다가 기관 지원 사업을 통해 재조성 혹은 환경개선을 하여 운영하는 경우가 $50.3 \%$ 로 조사 되었다. 학교 텃밭을 조성위치에 따라 4가지 유형(교내 텃밭 형, 교외 텃밭형, 상자 텃밭형, 혼합형)으로 구분하였는데, 혼합

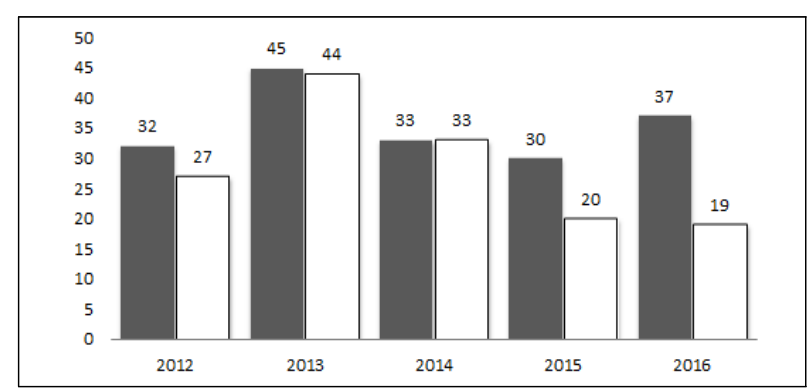

Figure 1. The number of setting up school gardens support of Seoul metropolitan government between 2012 and 2016

Legend:

- Number of setting up school garden

$\square$ Number of elementary school garden

Table 2. The number and area of elementary school gardens in Seoul

\begin{tabular}{c|c|c|c|c|c}
\hline \multirow{2}{*}{ Classification } & \multirow{2}{*}{$\begin{array}{c}\text { Number } \\
\text { of school }\end{array}$} & \multirow{2}{*}{$\begin{array}{c}\text { Number of } \\
\text { school garden }\end{array}$} & \multicolumn{2}{|c|}{ Area of school garden $\left(\mathrm{m}^{2}\right)$} \\
\cline { 5 - 6 } & & Sum & Average & $\begin{array}{c}\text { Per } \\
\text { student }^{11}\end{array}$ \\
\hline Seoul & 2,182 & $1,272(58.3 \%)$ & 166,901 & 131.2 & - \\
\hline $\begin{array}{c}\text { Survey of } \\
\text { elementary } \\
\text { school }\end{array}$ & $599^{2)}$ & $161(26.9 \%)^{3)}$ & 65,493 & 383 & 1.15 \\
\hline
\end{tabular}

1) The area per student: The area of garden/the number of all students

2) The survey of elementary school

3) The response of elementary school
형(교내 텃밭과 상자텃밭 조합)이 $34.8 \%$ 로 많았고, 교내 텃밭 형이 $32.9 \%$, 상자 텃밭형이 $29.2 \%$, 교외근린텃밭을 활용하는 교외 텃밭형 학교도 $3.1 \%$ 였다(Table 3 참조). 전북지역 초등 학교 텃밭 현황 분석에 따르면 교내텃밭이 $67.2 \%$, 교외텃밭 이 $17.2 \%$, 상자 텃밭이 $15.6 \%$ 였는데 (Jang et al., 2017), 혼합 형, 상자 텃밭형이 많은 서울시의 경우, 공간 확보의 어려움이 가장 큰 애로점으로 생각되었다. 이러한 공간문제 해결책으로 서울시의 경우, 옥상공간을 활용하여 텃밭을 운영하는 경우가 많은 것으로 보고한 것이 있다(Kim, 2014b). 학교 텃밭 교육이 학생들의 사회적 관계, 교우관계 개선(Hong and kim, 2017; Kim et al., 2012; Jeong and Lee, 2013), 주의집중력 향상(Lee et al., 2013) 등에 효과적이라고 다양한 연구에서 검토 및 보고 되고 있어 공간 확보가 어려워도 꾸준히 증가하고 있다. 특히 서울시 초등학교 텃밭은 학교 내 조성 공간이 부족한 경우가 많아 시 - 자치구 텃밭물품 지원 사업에서 학교 텃밭 운영 지원 등을 위해 상자텃밭을 많이 보급하는데, 앞으로도 옥상 및 노 지 상자형은 더욱 늘어날 것으로 예상된다.

학교 텃밭 운영책임자는 담당교사가 $51.6 \%$ 로 가장 높았으 며, 행정직원 $(24.5 \%)$, 교장·교감(14.9\%), 전담관리자 $(6.1 \%)$ 순으로 담당교사가 운영하는 곳이 많은 실정이었다. 도시농업 네트워크가 발달한 금천구, 도봉구 등에서 시-자치구에서 텃 밭관리사가 별도로 파견되어 관리하는 학교가 있었으나, 전체 적으로는 텃밭관리사가 파견되는 학교는 부족한 실정이다. 텃 밭 운영을 위한 평균 예산액은 150 만 원 수준으로 운영 예산이 없는 경우가 $44.1 \%$ 였으며, 50 만 원 이하가 $12.3 \%, 50 \sim 100$ 만 원 사이가 $22.9 \%, 100 \sim 200$ 만 원 사이가 $14 \%, 200$ 만 원 이상인 경우가 $7 \%$ 였다(Table 4 참조). 운영 예산이 없는 학교는 지원 에 의존해서 학교 텃밭 운영을 하고 있는 경우와 예산 확보 시 학교 텃밭 운영사항을 반영하지 못해 예산이 없는 경우가 많아 예산을 확보해서 학교 환경에 맞게 학생 교육에 활용하는 사례 들을 책자 등을 통해 안내할 필요가 있었다.

Table 3. The status of setting up elementary school gardens in Seoul

(unit: school number, \%)

\begin{tabular}{c|c|r|r}
\hline \multicolumn{2}{c|}{ Classification } & Frequency & Ratio \\
\hline \multirow{4}{*}{$\begin{array}{c}\text { Subject of } \\
\text { setting up }\end{array}$} & School & 19 & 11.8 \\
\cline { 2 - 4 } & School and external support & 81 & 50.3 \\
\cline { 2 - 4 } & External organization or institution & 61 & 37.9 \\
\cline { 2 - 4 } & Total & 161 & 100.0 \\
\hline \multirow{4}{*}{$\begin{array}{c}\text { Type of } \\
\text { school } \\
\text { garden }\end{array}$} & Garden outside the school & 5 & 3.1 \\
\cline { 2 - 4 } & Container in the school & 47 & 29.2 \\
\cline { 2 - 4 } & Garden in the school & 53 & 32.9 \\
\hline & Mixed(container \& garden) & 56 & 34.8 \\
\hline & in the school & 161 & 100.0 \\
\hline
\end{tabular}


Table 4. The status of running elementary school gardens in Seoul (unit: school number, \%)

\begin{tabular}{|c|c|c|c|}
\hline \multicolumn{2}{|r|}{ Classification } & Frequency & Ratio \\
\hline \multirow{6}{*}{$\begin{array}{l}\text { Subject of } \\
\text { running }\end{array}$} & (Assistant) principal & 24 & 14.9 \\
\hline & Teacher & 83 & 51.6 \\
\hline & Staff & 39 & 24.5 \\
\hline & Nutritionist & 5 & 2.9 \\
\hline & Custodian & 10 & 6.1 \\
\hline & Total & 161 & 100.0 \\
\hline \multirow{5}{*}{$\begin{array}{c}\text { Annual } \\
\text { school garden } \\
\text { budget }\end{array}$} & 0 won & 71 & 44.1 \\
\hline & 0 500,000 won & 20 & 12.3 \\
\hline & $500,001 \sim 1,000,000$ won & 37 & 22.9 \\
\hline & $1,000,001 \sim 2,000,000$ won & 23 & 14.0 \\
\hline & over $2,000,001$ won & 11 & 7.0 \\
\hline \multicolumn{2}{|r|}{ Total } & 161 & 100.0 \\
\hline
\end{tabular}

학교 텃밭 조성 시에 구성 및 설치요소(RDA, 2015)를 참고 하여 함께 조성된 시설물을 살펴보면 소형 온실 - 농기구 보관 함이 $26.1 \%$ 로 가장 많았고, 관수시설(24.8\%), 안전시설(9.3\%), 교육·휴게시설(8.1\%), 그 외 기타 $(8.1 \%)$, 빗물 재활용시설(1.9 $\%)$ 순이었다. 하지만 별도의 기반시설이 함께 조성되지 않은 경우가 $21.7 \%$ 로 조성단계에서 필요시설에 대한 고려가 부족 한 실정이다(Table 5 참조). 대부분의 학교에 설치된 시설물 인 틀텃밭, 농기구 보관함, 안전시설 등은 지속적 운영관리 및 학생들의 안전 등을 위해 친환경 방부목을 이용하여 만들어 설치되고 있었다. 학교 텃밭은 살아있는 생물을 다루는 공간이 며, 학생들을 대상으로 다양한 교육활동 등이 이루어지는 곳으 로 효율적 운영 및 활용을 위해 꼭 필요한 시설물을 조성 시 함께 설치하는 것이 중요한데, 아직 조성가이드 등이 미흡한 실정이다.

학교 텃밭 운영시 교육청 - 지자체 등 기관의 지원을 받는 경 우 지원물품을 조사하였는데, 물품 대부분은 학생 안전 등을 위해 친환경 인증제품을 지원하고 있었다. 지원물품은 상자텃 밭과 재배용 토양, 종자 - 모종 위주로 지원을 받는 학교가 많

Table 5. The status of facility supporting in elementary school gardens

(unit: school number, \%)

\begin{tabular}{c|c|c|c}
\hline \multicolumn{2}{|c|}{ Classification } & Frequency & Ratio \\
\hline \multirow{4}{*}{$\begin{array}{c}\text { Facility } \\
\text { in school } \\
\text { garden }\end{array}$} & Irrigation facility & 40 & 24.8 \\
\cline { 2 - 4 } & Rain recycling facility & 3 & 1.9 \\
\cline { 2 - 4 } & Greenhouse and tool shed & 42 & 26.1 \\
\cline { 2 - 4 } & Education and resting facility & 13 & 8.1 \\
\cline { 2 - 4 } & Safety facility & 15 & 9.3 \\
\cline { 2 - 4 } & Other & 13 & 8.1 \\
\cline { 2 - 4 } & No & 35 & 21.7 \\
\hline \multicolumn{2}{c}{ Total } & 161 & 100.0 \\
\hline
\end{tabular}

았으나, 상자 텃밭과 토양의 경우 부족하다고 답하는 학교도 있었고, 모종·종자, 비료, 방제제 등이 필요 이상 지급되고 있 다고 응답한 학교도 있어 일괄적 지원에서 수요와 공급이 일치 하지 않는 점을 확인할 수 있었다(Figure 2 참조). 학교 텃밭 운영 중 애로사항은 텃밭 관리의 어려움이 $34.2 \%$ 로 가장 높았 고, 과도한 업무(15.5\%), 재배관리 지식의 부족 $(8.1 \%)$, 교육 활용 $(3.1 \%)$, 예산 부족 $(1.9 \%)$, 텃밭공간의 협소함과 관리자 부족, 휴일 - 방학 중 관리의 어려움이었다. 이외 좁은 공간으 로 인한 이동 통로가 부족해서 불편함을 겪은 학교도 있었다 (Figure 3 참조).

\section{2. 학교 텃밭 조성 및 운영관리 현황}

학교 텃밭 조성목적은 교육환경 조성(81.6\%), 작물재배(10.5 $\%)$ 등(Figure 4 참조)으로, 학교 화단을 텃밭으로 변경하여 조 성한 경우가 $23.7 \%$ 로 가장 많았으며, 자투리땅을 찾아 텃밭정 원을 조성한 경우가 $14.5 \%$, 학교 설계 시 계획된 텃밭을 가지 고 있는 경우는 $10.5 \%$ 에 해당하였다(Figure 5 참조). 학교 내 공간이나 노지가 부족할 경우, 텃밭 조성 대안으로 옥상공간 에서 상자 텃밭을 활용하는 학교가 있는데, 안전이나 관리상의 문제로 잠가 놓는 경우가 많아 학생들이 자유롭게 이용할 수 없어 텃밭에 대한 애착이나 책임감을 갖는데 제한요소로 작용 하고 있으므로 안전펜스 등을 설치하여 안전하게 수시 출입이

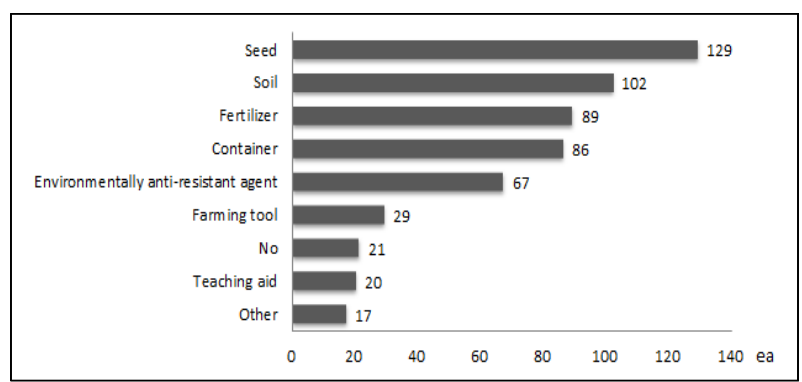

Figure 2. The status of materials supporting in elementary school gardens (duplicate response, $n=161$ (material supported= 153, not supported=8)).

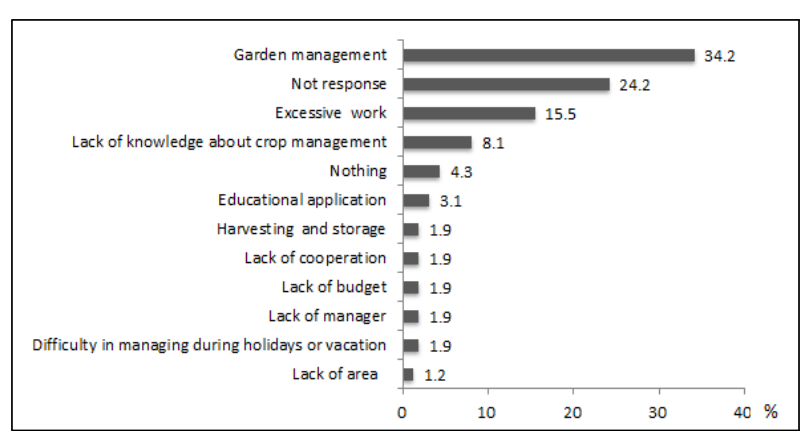

Figure 3. The difficulty in running elementary school gardens $(n=161)$ 


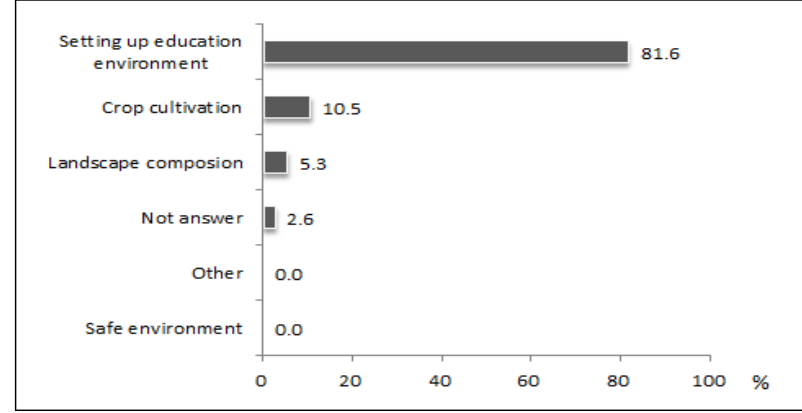

Figure 4. The purpose for setting up elementary school gardens $(n=76)$

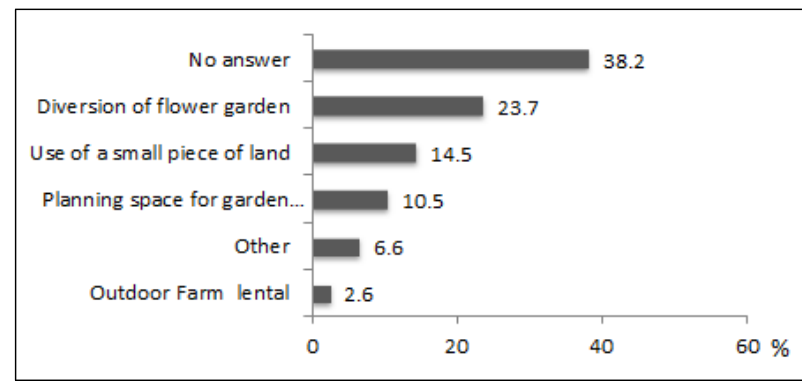

Figure 5. The securement of space for elementary school gardens $(n=76)$

가능한 방안을 강구하여 학교 텃밭을 운영하는 방안도 반드 시 검토되어야 할 것이다. 텃밭에서 주로 재배하는 식물은 엽 채류, 과채류, 허브류, 식량작물 순으로 많이 재배되고 있었으 며, 대부분의 학교가 작물선정에 있어 지원되는 모종·종자를 우선하여 재배하는 경우가 많았다(Figure 6 참조). 개별 구매 하여 이용하는 경우에는 구하기 쉽거나 키우기 쉬운 식물 위주 로 선정하는 것으로 조사되었다. 수확물은 수업시간에 활용하 는 경우가 가장 많았으며, 재배활동에 참여한 학생과 교직원 들이 나누거나, 친환경 급식에 활용하기도 하였다. 텃밭 수확 물을 급식에 활용하기 위해서는 영양교육과 텃밭체험 교육활 동이 병행되면 채소 편식 감소 외에 타인조절, 자기조절능력이 높아진다고 보고(Cotugna et al., 2012; Son et al., 2015) 되었는 데, 식생활 연계 프로그램개발 및 적용도 시도되어야할 것이다.

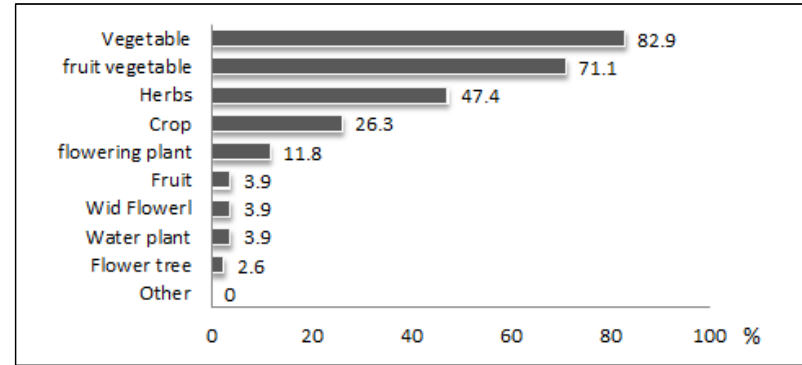

Figure 6. Selection plants for elementary school gardens (duplicate response, $n=76$ )
하지만 친환경 학교급식에 활용하기 위해서는 철저한 품질검 사 등이 필요한데, 텃밭 수확물을 활용한 교육프로그램을 개발 할 때 조건에 맞는 재배조건을 고려해서 운영해야 한다.

텃밭에서 식물재배 관련 활동은 꾸준히 이어지고 있는 것으 로 조사되었고, 학내 구성원들이 친환경적으로 유기농재배 위 주의 활동을 하는 것으로 나타났다. 운영하는 텃밭이 교재원으 로 활용되고 있으나. 학교 텃밭이 학습교재원으로써 기능하기 위해서는 식물의 선정과 재배, 텃밭디자인에서 도움이 필요할 것으로 보인다. 조성된 텃밭 공간의 형태나 위치, 토양, 배수 등 에서는 전반적으로 만족하고 있으나, 텃밭 규모가 작고 예산이 부족하다는 의견이 많은 편이었다(Figure 7 참조). 텃밭에서 발생하는 수확물 이외 식물 생쓰레기를 퇴비화 하는 학교는 조사학교의 $45.8 \%$ 이고, 종량제 봉투로 배출하는 경우가 $29.2 \%$, 학교 인근 유휴지나 산지에 매립한다는 답변도 $12.5 \%$ 로 조 사되어 텃밭을 운영할 때 발생하는 식물쓰레기 퇴비화 시설과 방법에 대한 안내와 쓰레기를 줄이는 방안에 대한 고민이 함 께 이루어져야 할 것으로 보인다(Figure 8 참조). 텃밭관리에 필요한 정보는 주로 주변자문(67.8\%)을 통해서 얻고 있으 며, 인터넷 $(23.7 \%)$, 교육연수(5.1\%)를 통해서도 얻고 있었다 (Figure 9 참조). 텃밭관리를 위한 담당교사 교육연수의 필 요성에 대해서는 설문조사 학교 대부분이 필요하다고 하였으 며, 필요로 하는 연수내용으로는 식물재배(40.0\%), 텃밭 관리 (20.0\%), 교육과정 연계(8.6\%), 병해충 관리(5.7\%), 토양관리

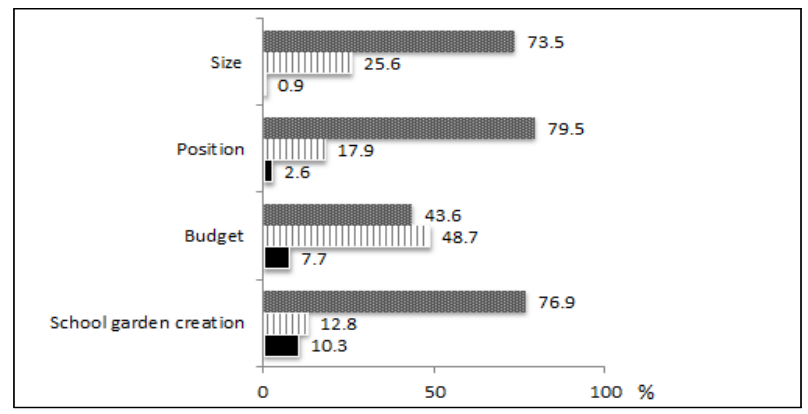

Figure 7. The satisfaction about the school garden (duplicate response, $n=76$ )

Legend: 露 Satisfaction |I Dissatisfaction - Not answer

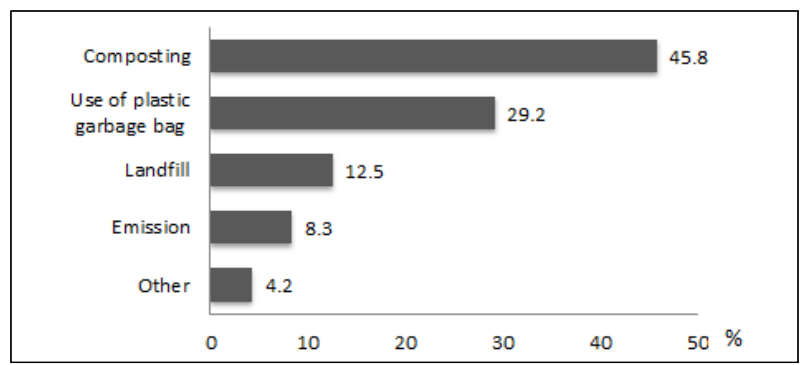

Figure 8. The way to dispose of farm produce sewage $(n=72$, no answer $=4$ ) 


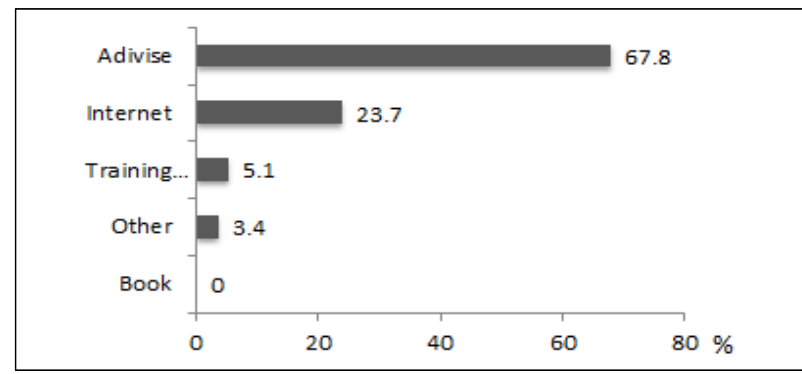

Figure 9. The acquisition method of information and knowledge about elementary school gardens $(n=59$, no answer = 17)

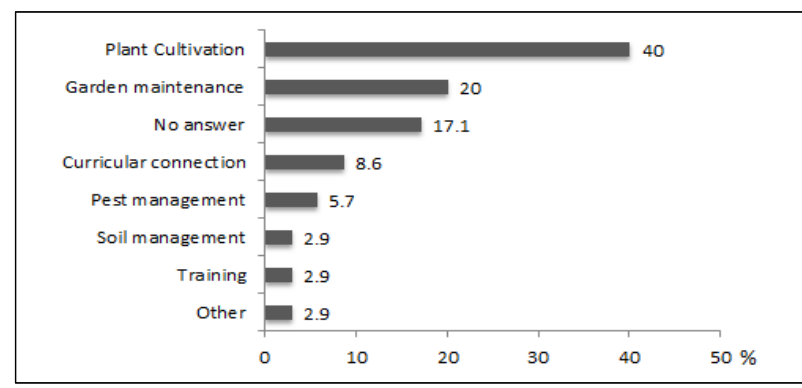

Figure 10. The teacher training contents necessary for managing elementary school gardens (duplicate response, $n=76$ )

(2.9\%), 실습(2.9\%) 등이었다(Figure 10 참조).

학교 텃밭 관리 애로사항은 텃밭 관리의 어려움, 텃밭에 대 한 정보 및 관리 지식의 부족, 예산 부족, 전문가 확보 및 수업 연계의 어려움, 시설 부족, 공간 확보의 어려움, 참여자의 관심 및 참여 부족으로 구분하고, 우선 순서대로 3순위까지 조사하 여 순위별 가중치(1순위: 3점, 2순위: 2점, 3순위: 1점)를 주어 계산한 뒤 최고값을 100 으로 하여 나타냈다. 학교 텃밭 관리의 어려운 점으로는 기존 업무이외에 텃밭 관련 담당업무가 추가 되어 업무수행에 부담을 느낀다는 의견이 $27.4 \%$ 로 가장 높았 고, 전문지식이 부족하여 관리가 어렵다는 의견이 $21.2 \%$ 였다. 휴일 및 방학 중 관리 $(15.3 \%)$, 병충해관리 $(14.2 \%)$ 등에도 어 려움을 느끼고 있는 만큼 관리에 드는 노동력과 시간을 절약 할 수 있는 방안 또한 함께 고민하여야 할 것이다(Figure 11

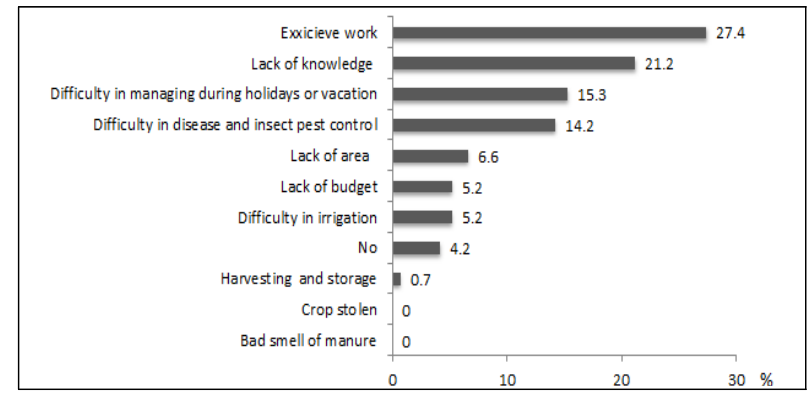

Figure 11. Lack of managing elementary school garden (duplicate response, $n=76$ )
참조). 특히 여름방학 중에 정리되지 않은 채 방치되는 경우, 미 관상이나 환경적으로 좋지 않은데, 관리문제에 대한 해결책이 모호한 실정이다. 최근 방학 중 텃밭관리 방안에 대한 매뉴얼 이 개발되고 있는데, 학교에서 활용할 수 있도록 텃밭 관리 시 작 전에 보급할 필요가 있다.

기관을 통해 물품이 아닌 금액 지원을 받게 되면 텃밭의 물 리적 환경 개선을 위해 사용하겠다는 학교가 $38.2 \%$ 였으며, 모 종 등 식물자재 구입과 유급관리인 고용에 사용하겠다는 학교 가 각각 $26.3 \%$ 와 $23.7 \%$ 로 조사되었다. 또한 텃밭 운영 - 관 리를 위해 가장 필요한 요소로 물리적 환경 개선과 유급관리 인 고용이 필요하다는 의견이 각 $32 \%$ 로 높은 비율로 조사되었 고, 지속적인 텃밭 운영을 위해서 전담관리사가 필요하다는 의견이 많았으며, 운영- 관리 매뉴얼의 필요성과 예산 확보 역시 지적되었다. 텃밭을 중도에 포기하지 않고 지속적으로 운 영하기 위해서는 전문지식 부족을 해소할 수 있는 관련 교육의 실시(18.4\%)와 담당교사에게 집중되는 업무 과중을 분산하고, 공동으로 운영할 수 있는 방안과 구성원의 의지가 중요하다는 의견도 있었다(Figure 12 참조).

\section{3. 학교 텃밭 운영: 교육적 활용}

학교 텃밭의 교육적 활용에 관한 조사에서 2년 이상에 걸쳐 지속적으로 교육을 진행하고 있는 학교가 $71.1 \%$ 였고, 조사연 도부터 시작한 학교가 $14.5 \%$ 였다. 텃밭은 있지만 교육활용을 하고 있지 않는 학교도 $7.8 \%$ 였고, 예전에는 교육이 있었으나, 조사 연도에는 교육이 없는 경우(1.3\%)도 조사되었다(Figure 13 참조). 요즘 학생들은 다양한 교과활동을 하고 있는데, 수업 내용, 활용교과목 등이 미흡하여 정규 교과과정에 활용되지 못 하고 방과 후 활동 등 다른 교육으로 이루어지는 경우도 있었 다. 정원기반 교육은 학문적 기술, 개인적 발달, 사회적 발달, 도덕 발달, 직업적 혹은 생존 기술, 삶의 기술들을 포함하는 기초 교육의 모든 측면들에 기여하는데(Oh and Choi, 2006), 학교 텃밭을 활용한 교육도 초등학생 학교생활에서 교우관

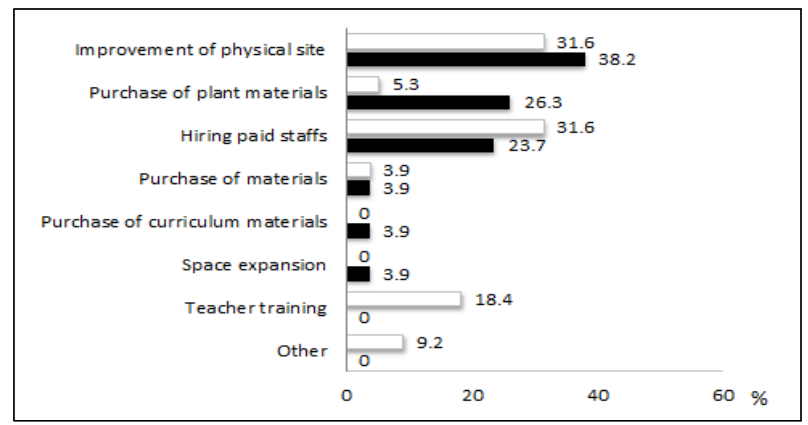

Figure 12. The plan for grant use and the most necessary for managing school gardens $(n=76)$

Legend: $\square$ Plan for grant use $\square$ The most necessary 


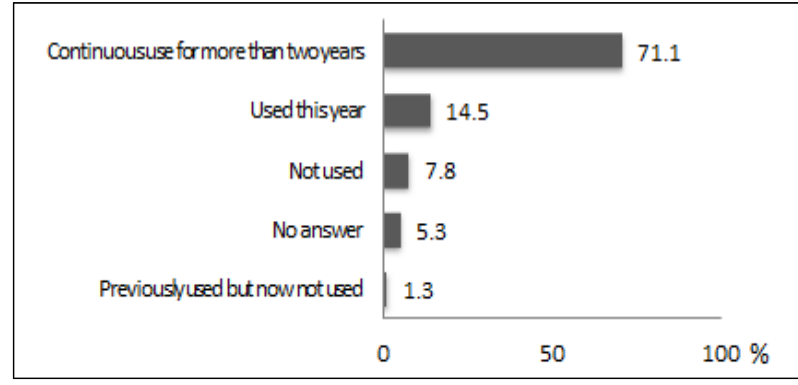

Figure 13. The use of school garden for academic content instruction $(n=76)$

계 개선(Lee et al., 2017a), 사회성 증대 효과(Kim and Jeong, 2008; Kim, 2013), 지적장애학생들을 대상으로 한 직업적응력 증진(Joo et al., 2012)효과, 학교 폭력 감소(Lee et al., 2017b) 등이 보고되고 있다. 이외에도 학교 텃밭에서 체험활동을 통해 과학 등 교과학습에 대한 흥미유발 학습 수행 능력이 향상되 었다고 하였고(Moon et al., 2012; Jung et al., 2013), 자연과 생명에 대한 소중함을 일깨우고 환경에 대한 생각 및 태도에 긍정적 영향을 미친다고 보고하였다(Paek, 2012).

텃밭 교육이 현재 있거나 과거에 진행했던 학교는 정규수업 시간에 진행되고 있는 경우 창의적 체험활동 시간 $(53.6 \%)$ 중 이루어지는 경우가 가장 많았고, 특별활동 형태의 교육활동이 $37.7 \%$ 였다(Figure 14 참조). 창의적 체험활동이나 특별활동 형 태로 수업이 진행되는 경우에는 특정학급이나 동아리가 참여 하는 경우가 많고, 전문 강사에 의한 교육프로그램으로 진행되 었다. 텃밭 교육이 정규교과와 연계된 수업은 전문 강사나 담 임교사에 의해 진행되었고, 실과 $(35.6 \%)$, 과학(8.9\%)순이었으 며, 기타 $(55.5 \%)$ 로 응답한 내용을 분석해보니 창의적 체험활 동 시간에 연계된 경우가 많았다(Figure 15 참조). 해당 설문 에 무응답자가 많아 응답수 중의 비율을 제시하였으며, 텃밭체 험활동을 특정 교과와 연결지어 진행하는 경우가 많지 않음을 시사하였다.

수업에 필요한 준비물은 기관의 지원으로 배부된 자재를 활 용하는 경우가 많았으며, 자체적으로 준비하여 진행하는 학교

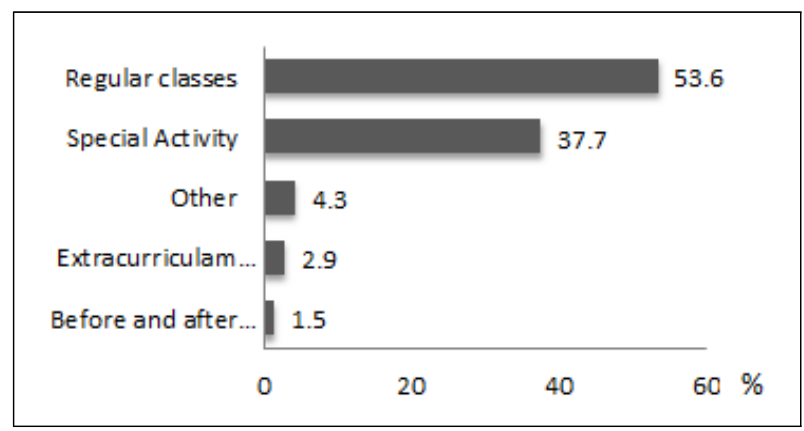

Figure 14. Classes or time when the school garden is used (experience in school garden education program, $n=69$ )

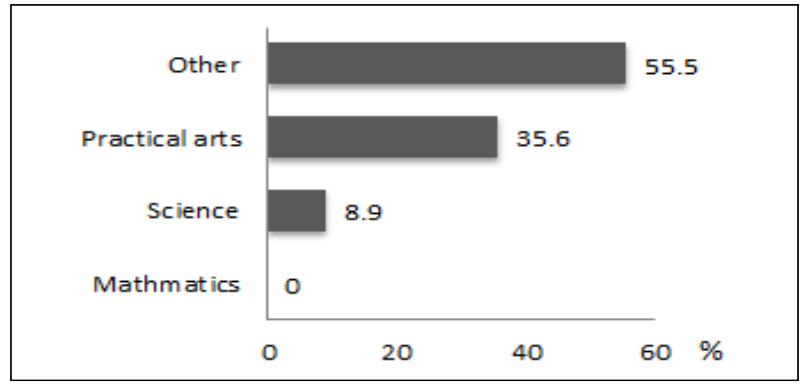

Figure 15. Academic subject in which the school garden is used $(n=45$, no answer $=31)$

도 있었다. 텃밭 교육의 효과에 대해서는 대부분 매우 긍정적 이었음에도 수업시간 배정이나 교육 진행을 위한 강사 섭외, 공간부족 등 현실적인 이유로 진행하지 못하는 경우가 있었다. 텃밭 교육의 시행 빈도는 학교별로 차이가 많았으나, 월 2회 정 도 진행하는 학교가 가장 많았으며, 작물의 재배와 수확시기에 맞춰 진행되고 있었다(Figure 16 참조). 진행이 잘 되고 있는 학교의 경우, 주 1 회 이상으로 수업이 늘어나기를 희망하는 한 편, 오히려 현재보다 줄어든 월 1 회 이하를 희망하는 학교도 많아 텃밭교육에 어려움을 겪고 있는 모습을 확인할 수 있었 다. 설문에 응답한 교사가 학교를 대표하는 의견이 아닌 개인 의사를 반영하게 되는 것에 대한 부담감 등을 표현하며, 응답 하지 않은 항목들이 있어 표본수가 많지 않아 분석에 한계가 있었다. 학교 텃밭의 교육적 활용이 학생들에게 미치는 영향 에 대해서는 매우 효과적이라는 응답이 $63 \%$, 효과적이라는 응 답이 $37 \%$ 로 조사대상 학교 전체가 긍정적인 응답을 하였다 (Figure 17 참조). 텃밭 관련 교육이 학교에서 이루어지고는 있 지만, 활동시간과 수업시간 확보가 어려운 학교 현실 속에서 교 육프로그램이 계획되어 진행되는 것이 아니라. 시기별 이벤트나 단순한 재배작업에 집중하는 경우가 많았다. Skelly와 Bradley (2000)는 초등학교 교사들이 학교 텃밭을 활용한 수업지도에 익숙지 않아 교과수업과 효율적으로 연계하는데 어려움이 있 다고 판단하였고, Graham 등(2005)은 미국 캘리포니아주 학 교 교장을 대상으로 한 설문조사에서도 교과수업연계 및 교과

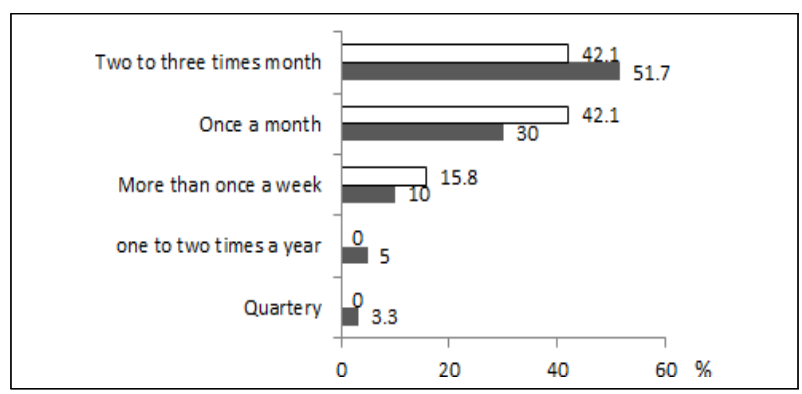

Figure 16. Current and desired class interval which the school garden is used ( $n=60$ and 19 , respectively)

Legend: $\square$ Current class interval $\square$ Desired class interval 


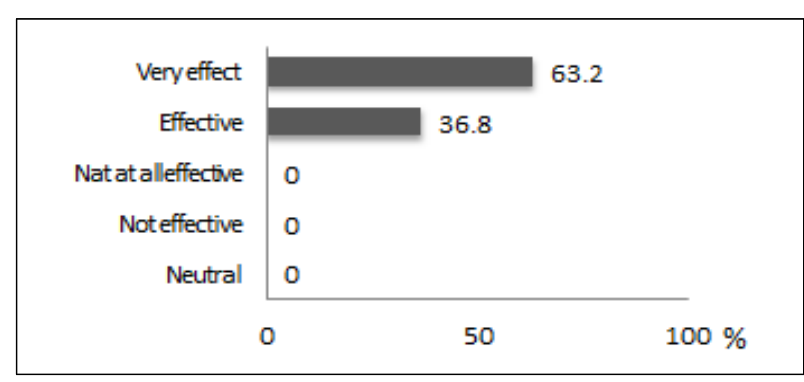

Figure 17. The satisfaction of school garden on students $(n=76)$.

연계 수업재료 부족을 애로사항인 것으로 보고하였는데, 학생 들이 지속적으로 텃밭과 식물이 자라는 과정을 관찰하고 기록 하며, 텃밭체험에 그치지 않고 양질의 교육으로 이어질 수 있 도록 도울 수 있는 방법을 강구해야 한다.

\section{V. 결론 및 제언}

본 연구는 서울시내 초등학교를 대상으로 일반사항, 텃밭 조 성, 운영 및 관리, 교육활용 현황 등을 조사하여 학교 텃밭의 지속적 관리를 위한 방안을 제시하였다. 도시농업 활성화로 학 교 텃밭의 양적인 확대가 이루어졌는데, 교사와 학생, 학부모 등을 대상으로 텃밭 관리 애로사항을 파악하여 내실 있게 운영 할 수 있는 방법을 제시할 필요성이 있다.

조사대상 초등학교에서 자체적으로 학교 텃밭을 조성 - 운영 하는 경우도 있었으나, 학교 자체적으로 조성하여 운영하다가 기관 지원 사업을 통해 재조성 혹은 환경개선을 하여 운영하는 경우가 많았다. 학교 텃밭을 조성위치에 따라 교내 텃밭형, 교 외 텃밭형, 상자 텃밭형, 혼합형으로 4 가지 유형으로 구분하 였는데, 혼합형(교내 텃밭과 상자텃밭 조합)이 가장 많았다. 학 교 텃밭은 담당교사가 운영하는 곳이 많았으며, 텃밭관리전문 가가 별도로 파견되어 관리하는 학교도 조사되었다. 학교 텃밭 조성 시에 함께 조성된 시설물을 살펴보면 소형 온실 · 농기구 보관함이 가장 많았으나, 별도의 기반시설이 함께 조성되지 않 은 경우도 있었다. 학교 텃밭은 거의 대부분 교육환경조성을 목적으로 운영되고 있으며, 학교 화단을 텃밭으로 변경하여 조 성한 경우가 많았다. 텃밭에서 주로 재배하는 식물은 엽채류, 과채류, 허브류, 식량작물 순으로 식물재배 관련활동은 꾸준히 이어지고 있는 것으로 조사되었다.

텃밭관리에 필요한 정보는 주로 주변 자문을 통해서 얻고 있 으며, 텃밭 관리의 어려운 점으로는 업무수행에 부담을 느낀다 는 의견이 가장 높았고, 전문지식이 부족하여 관리가 어렵다는 의견도 있었는데 텃밭 담당자 직무교육이 식물재배와 텃밭관 리 중심으로 이루어지길 원했다. 또한 텃밭 운영 - 관리를 위해 물리적 환경 개선과 유급관리인 고용이 필요하다고 응답하였 다. 텃밭 교육이 정규교과와 연계된 수업은 전문 강사나 담임
교사에 의해 실과, 과학 순으로 진행되었으며, 창의적 체험활동 시간에 연계된 경우가 많았다. 학교 텃밭의 교육적 활용이 학 생들에게 미치는 영향에 조사대상 학교 전체가 긍정적인 응답 을 하였는데, 수업시간 배정이나 교육 진행을 위한 강사 섭외, 공간부족 등 현실적인 이유로 진행하지 못하는 경우도 있었다.

중앙정부나 지자체를 통해 텃밭조성에 다양한 예산지원이 이루어지고 있는데, 학교의 특성 및 여건을 고려한 체계적인 맞춤형 지원이 필요하다. 학교 행정특성상 2월에 담당자가 배 정되고, 업무인수인계 등이 원활하지 않아 해마다 운영상 문제 가 발생하는데, 매년 말 학교 텃밭 운영관리 결과보고를 통해 다음해에 필요한 시설물, 자재 등을 기입하여 중복지원에 대한 예산낭비나 꼭 필요한 물품이 지원되지 않아 겪게 되는 어려움 을 감소시키기 위한 방법이 적극적으로 검토되어야 할 것이다. 또한 처음 조성하는 학교의 경우, 학교 텃밭 조성 초기 텃밭 디 자인, 필요한 시설물 등에 대한 안내가 되어야 하며, 기 조성된 학교의 경우 유지관리를 위한 매뉴얼 보급, 텃밭관리 전문가 파견과 교육적 활용을 위한 전문 강사 지원이 이루어져야 한다.

학교 텃밭 조성은 식물재배 공간 부족, 관리의 복잡성을 고 려하여 구성 요소 및 관련 시설을 구비할 수 있도록 하여야 한 다. 학교 텃밭을 조성하기 전 목적을 분명히 하고, 그에 부합하 도록 체크리스트를 만들어 준비를 철저히 하여야 한다. 조성 할 부지의 확보, 공간 활용에 대한 이해, 자원조달, 전문지식과 경험이 있는 책임자 선정, 운영 프로그램 계획 등의 조건을 갖 추고 확인해야 한다. 또한 텃밭 조성과 함께 설치되어야 할 필 요시설에 대한 고려도 동시에 이루어져야 운영할 때 어려움을 줄일 수 있다.

학생들의 정서를 함양하고 학습을 도울 수 있는 학교 텃밭 교육 중요성은 날로 부각되고 있다. 텃밭활동은 교실 안에서만 이루어지는 것이 아니라, 학생들이 직접 밖으로 나와 체험해 보 고 느낌으로써 그 효과는 한층 더 커질 수 있고, 다양한 체험활 동을 통해 자연을 이해하고 사랑하는 마음이 저절로 생겨나게 될 것이다. 학생들이 텃밭과 작물의 변화를 관찰하고 기록하며, 텃밭체험에 그치지 않고 양질의 교육으로 이어질 수 있도록 도 울 수 있는 방법을 강구해야 한다. 또한 텃밭담당교사 직무교 육 및 텃밭관리전문가 역량강화 교육이 고려되어야 한다. 최 근 텃밭담당교사 직무연수가 주 5일(40시간) 과정으로 특 - 광 역시 등에서 교육되고 있는데, 다양한 연구과정, 예를 들면 텃 밭디자인, 재배식물관리, 교육 프로그램 활용 등을 편성하여 수준별 연수지원이 가능하도록 해야 할 것이다.

다양한 교육프로그램이 개발되어 학교 텃밭 교육프로그램 매 뉴얼로 소개되고 있으나, 1 회성 이벤트 중심, 노작중심의 교육 프로그램이 많아 학생들의 교과목 수업과 연계되어 연중 이어 지는 특성화 수업 프로그램개발이 절실하다. 과학, 사회, 국어, 음악, 미술 등 다양한 교과와 연계한 텃밭을 활용한 융합형 교 육 프로그램 운영으로 교육적 효과를 높이면서 학생들이 적 
극적으로 텃밭운영에 참여할 수 있는 프로그램 및 학년별 특성 이나 교과특성이 반영된 맞춤형 특성화 프로그램을 계속해서 개발하여야 한다. 이와 함께 교육프로그램 운영 시 활용할 수 있는 학습교구개발 및 보급도 함께 되어 원예 관련 산업 활성 화도 같이 되어야 할 것이다.

많은 연구를 통해 밝혀진 바와 같이 학교 텃밭의 긍정적 효 과를 교육에 활용하고 지속적으로 운영이 가능한 학교 텃밭환 경을 만들기 위해서는 보다 체계적인 텃밭관리조직이 필요한 실정이다. 인력 변동이 항상 발생하는 학교 환경을 고려하면 지속적인 관련 교육 실시와 운영매뉴얼을 통해 조성과 운영 관리에 대한 기준을 마련하고, 학내 구성원과 유관기관, 전문가, 자원봉사자 등의 네트워크 구성을 통한 안정적인 기술지원이 도움이 될 것이다. 본 연구의 사례 조사에서 나타난 바와 같이 담당교사의 의지만으로는 텃밭운영을 감당하기 어려우므로, 텃 밭전문가, 학부모, 자원봉사자 등의 참여 확대와 시 - 자치구 관 련 부서의 체계적인 기술적 지원방안을 마련하여, 학교 텃밭 관리의 가장 큰 애로사항으로 지적된 운영관리 전문지식 부족 등의 문제를 해결해 나갈 수 있을 것이다. 자문을 통해 텃밭운 영 관련 문제를 해결하는 경우가 많았는데, 운영할 때 애로사 항을 묻고 해결책을 빨리 찾을 수 있는 $\mathrm{Q} \& \mathrm{~A}$ 게시판도 농업기 관 및 교육청 홈페이지 학교농장 배너도 개설하게 되면 학교 텃밭 운영에 도움이 될 것으로 판단된다. 또한 농업관련 경험 이 부족한 경우에도 쉽게 활용할 수 있도록 학교 텃밭의 조성 과 운영, 교육적 활용에 대한 매뉴얼을 제작, 보급과 이미 개발 된 다양한 교육프로그램을 연계, 소개하는 정보제공 서비스 등 이 마련되는 것도 학교 텃밭의 교육적 활용에 도움을 줄 수 있 을 것으로 생각된다.

주 1. 경기농림진흥재단(http://greencafe.gg.go.kr/works/54864)

주 2. 사이타마현 녹색학교팜추진매뉴얼(https://www.pref.saitama.lg.jp/ kyoiku)

주 3. 사이타마현 녹색학교팜추진매뉴얼(https://www.pref.saitama.lg.jp/ kyoiku)

주 4. 서울특별시농업기술센터 전자책(http://agroseoul.net)

\section{References}

1. Arden, B. S. and R. K. Pringle(2010) How to Grow a School Garden: A Complete Guide for Parents and Teachers. Timber Press.

2. Ansan Urban Agricultural Coalition(AUAC) (2015) Survey on Education of School Garden in Ansan Area for Strengthening Hands-on Environmental Education.

3. Cotugna, N., C. K, Manning and J. Didomenico(2012) Impact of the use of produce grown in an elementary school garden of consumption of vegetables at school lunch. Journal of Hunger \& Environ. Nutrition 7: 11-19.

4. Graham, H., D. L. Beall, M. Lussier, P. Mclaughlin and S. ZidenbergCherr (2005) Use of school gardens in academic instruction. Journal of Nutrition Education and Behavior 37(3): 147-151.

5. Hong, E. S. and J. H. Kim(2017) The effect of the school farm program on the personality of elementary school students. The Journal of Korean Practical Arts Education 23(1): 163-186.

6. Jang, J. and C. H. Oh(2012) Needs analysis of experiential learning program for eco-friendly school farm activation: Target of teachers in elementary school. Korea Journal of Organic Agriculture 20(3): 283-296.

7. Jang, J., K. Y. Lee and C. H. Oh(2011) Study on characteristics of school farm type in the Seoul metropolitan area. Journal of Korean Society of Environment \& Ecology 21(2): 120-123.

8. Jang, Y. O., S. J. Jeong, K. S. Han, K. M. Kim, I. J. Choi and J. N. Heo(2017) Set up and rinning status of school gardening at elementary schools: Fosus on Jeollabuk-do. Korean Journal Community Living Science 28(4): 613-623.

9. Jeong, Y. O. and J. H. Lee(2013) The effect of the horticultural activity on the sociality and friend relation of elementary school students. Journal of Korean Practical Arts Education 26(3): 41-58.

10. Joo, B. S., S. A. Park and K. C. Son(2012) Improving work adjustment skills in students with mental retardation using hydroponics program. Korea Journal Horticulture Science Technol 30(5) : 586-595.

11. Jung, M. S. and G, H. Bang(2008) The effects of plant cultivation activities upon elementary school student's self-esteem. The Journal of Korean Practical Arts Education 21(1): 37-61.

12. Jung, S. J., J. H. Moon, S. M. Lee and H. J. Jo(2013) Effects of inquiry activity through growing lettuce on science inquiry skills for five grade elementary school students. Journal of Agricultural Extension \& Community Development 20(4): 1023-1043.

13. Kim, H. J.(2013) Analysis of attitude changes of elementary students toward work through school garden experience. The Journal of Korean Practical Arts Education 19(4): 103-127.

14. Kim, J. H.(2009) The effect of the plants eduction on the personality of elementary school students. The Journal of Korean Practical Arts Education 15(4): 127-140.

15. Kim, K. R. and Y. O. Jeong(2008) The effect of vegetable gardening on society among elementary school students. Journal of Korean Practical Arts Education 21(1): 153-165.

16. Kim, S. S., S. A. Park and K. C. Son(2012) School gardening program for improving social relations of elementary school students. Korea Journal Horticulture Science Technol 30(2) : 175.

17. Kim, Y. J.(2014a) Influence of Construction and Use of School Garden in Elementary School on Recognition of Teachers, Parents and Students. Master's Thesis, Korea University. Korea.

18. Kim, Y. K. (2014b) Analysis of Current Operational State of Vegetable Gardens by Elementary School and Plans for Activation. Master's Thesis, Seoul National University of Education. Korea. pp. 21-22.

19. Korean Educational Development Institute(KEDI) (2016) Statistical Yearbook of Education 2016. Korean Educational Development Institute, Jincheon.

20. Kwack, H. R., S. W. Han and S. H. Kim(2007) Effect of integrative environmental program focused on horticultral topics to the environmental attitude and scholarlic achievement of elementary school students. The Journal of Korean Practical Arts Education 20(3): 63-78.

21. Lee, M. J., J. S. Kim, W. Oh and J. S. Jang(2013) Effects of indoor horticultural activities on improvement of attention and concentration in elementary school students. Korea Joumal Horticulture Science Technol 31(6) : 821-827.

22. Lee, J. J., I. J. Choi, J. C. Joo, M. S. Kim, S. T. Cho, H. G. Son, Y, A. Jang, J. N. Heo and S. Y. Kim(2017a) Development of activity program with gardening experience improving peer relation problems. Journal of Agricultural Education and Human Resource Development. 
$49(4): 1-17$

23. Lee, J. J., I. J. Choi and S. T. Cho(2018) Development and application of creative elementary agricultural education program using 3D printer. Journal of Agriculture Education and Human Resource Development. 50(1): 231-248.

24. Lee, S. E., C. H. Oh and S. H. Lee(2017b) A study on the effect of school gardening program for the countermeasure of school violence. Proceedings of the KILA Conference, pp. 58-59.

25. Lee, S. W. and J. W. Kim(2014) Analysis of implementation case and investigation of educational effect for general agricultural education in school farming. Journal of Leaner-Centered Curriculum and Instruction 14(11): 547-571.

26. Ministry of Agriculture Food and Rural Affairs(MAFRA)(2013) The 1st Five-year-plan for Growth of Urban Farming. A Report of MAFRA, Sejong.

27. Ministry of Agriculture Food and Rural Affairs(MAFRA)(2017) 2016 Urban Farming Status Report. MAFRA, Sejong.

28. Ministry of Agriculture Food and Rural Affairs(MAFRA) (2018) The 2nd Five-year-plan for Growth of Urban Farming. A Report of MAFRA, Sejong.

29. Moon, J. H., S. M. Lee, S. J. Jung, Y. S. Lee, H. R. Kwack and Y. I. Song(2012) Effects of container vegetable gardening on the improvement of scientific interest, social ability and academic achievement for elementary students. Journal Korean Society People Plants Environment 15(6): 421-428.

30. Oh, D. M. and Y. A. Choi(2006) Urban Agriculture which Comes out as Meeting with Nature and Heal the World. Hakjisa.

31. Park, J. W. and G. B. Ahn(2013) The current status of the Korean urban farming researched from an institutional perspective and tasks for the future. Journal of Korean Society of Rural Planning 19(3): 61-73.

32. Paek, K. W.(2012) A Environmental Education Plan Applying School Gardening in the Elementary School. Master's Thesis, Seoul National University of Education. Korea. pp. 4-8.

33. Rural Development Administration(RDA) Republic of Korea(2015) Garden and Urban Greening (The Textbook for Farming no. 206). RDA, Jeonju, pp. 107-114.

34. Seoul Metropolitan Government(SMG) (2017) Department of Urban Farm: City Farm Status Report. SMG, Seoul.

35. Seoul Metropolitan Government(SMG) (2018) Department of Urban Farm: City Farm Status Report. SMG, Seoul.

36. Skelly, S. M. and J. C. Bradley (2000) The importance of school gardens as perceived by florida elementary school tachers. Horticulture Technology 10(1): 229-231.

37. Son, M. S., T. J. Suh and H. S. Kim(2015) Economic valuation methods to evaluate the progressive change in values of urban farming. Journal of the KRSA. 29(1): 67-84.

38. Yu, M., M. J. Lim and E. H. Lee(2012) The present condition investigation of use of school farming: Focus on Nowon-gu and Songpa-gu Area. Journal Korean Society People Plants Environment. 15(3): 179-184

Received : 18 June, 2018

Revised : 02 July, 2018

31 July, 2018

Accepted : 31 July, 2018

(1st)

(2nd)

3인익명 심사필 